\title{
INHIBITION OF LIPID OXIDATION OF THE FROZEN MUSCLE TISSUE OF HERRING USING MUSTARD
}

\author{
HAMOWANIE UTLENIANIA LIPIDÓW MROŻONEJ TKANKI \\ MIEŚSIOWEJ ŚLEDZI, PRZEZ ZASTOSOWANIE GORCZYCY
}

\author{
Department of Refrigeration, Agricultural University of Szczecin, Poland \\ Content of hydroperoxides, secondary products of oxida- \\ tion, dienes and trienes was analysed in a minced muscle tissue \\ of Baltic herring treated with white mustard while, stored \\ at $-25^{\circ} \mathrm{C}$
}

\section{INTRODUCTION}

One of more important reasons for quality worsening of fish minced meat under condition of frozen storage is oxidation of its unsaturated fatty acids. The resulting products of this oxidation process are harmfil to human health, because they react easily with biomolecules responsible for regulation of the organism functions (Murphy 1990), serious impairment of its functions (Block 1992), and they may lead to a number of diseases or discrders (Ames 1983). It has been known that lipid oxidation processes can be prevented or inhibited by additives of antioxidative substances, possibly very actively affecting unsaturated fatty acid and at the some time being nutritive to humans. Such role in relation to the lipids of the muscle tissue of fishes can be played by some plant-origin antioxidants (Taniguchi et al. 1988; Romanathan and Das 1993; Stodolnik 1995). Because the activity of natural antioxidants is lower than the activity of efficient, synthetic buthylated hydroxyanisole (BHA) the quest is on for new sources of antioxidants able to inhibit oxidation of the lipids of the muscle tissue of fishes-ranked among the highly unstable foodstuffs.

Among known research results on the antioxidative activity of plant-origin products no information had been found on possible antioxidative properties of the white mustard and its extracts. Therefore the present authors attempted to conduct research whether and in what extent the white mustard and its aqueous extract can have impact on inhibition of 
lipids present in the muscle tissue of herring under conditions of frozen storage. Additional reasons, for selecting the white mustard for this kind of study, were: its importance in the food industry, also in fish processing and the presence of medically important compounds found in this plant (Nowiński 1990; Grau et al. 1996).

\section{MATERIAL AND METHODS}

\section{Material}

The research material were Baltic herring (Clupea harengus L.) caught on the beginning of March 1997. The fish represented V/VI stage of gonad development according to Maier. Their average length was $28 \mathrm{~cm}$, the average weight $-190 \mathrm{~g}$ and they were processed at the stage of fading rigor mortis. The fish were filleted and skinned and than minced on an electric grinder with a 3-mm plate. The minced muscle tissue was divided into 350-g portions. Each portion was mixed with one of the following additives: ground seeds of the white mustard (Sinapis alba L.) in the proportion of $0.25,0.50$, and $0.75 \%(\mathrm{G})$, aqueous extract of white mustard seeds in the proportion of 0.50 and $0.75 \%$ (GE) equal to 0,50 - and $0.75-\%$ (respectively) addition of the white mustard to the muscle tissue of herring. One of the experimental treatments constituted a sample with $0.01-\%$ addition of buthylated hydroxyanisole (BHA), while the control sample - minced meat without additives. From each experimental treatment a total of six 50-g samples was taken. The samples were formed into 1-cm-thick bars, wrapped into a polyethylene foil and frozen at $-25^{\circ} \mathrm{C}$. The samples after freezing were stored also at $-25^{\circ} \mathrm{C}$ for three months.

Preparation of the white mustard extract

Ground white mustard was soaked with distilled water in the proportion of 1:4, stirred for 30 minutes and subsequently centrifuged at 3500 RPMs for 15 minutes. The supernatant liquid following its separation was heated in a water bath for 5 minutes to inactivate enzymes and centrifuged again under the above-mentioned conditions.

\section{Methods}

Muscle tissue lipids were extracted using a mixture of chloroform and methanol (Linko 1967). Hydroperoxides in the chloroform layer were analyzed by a direct method oxidizing them with $\mathrm{FeCl}_{3}$ to malonaldehyde. The latter reacts subsequently with 2-thiobarbituric acid (Schmedes and Hølmer 1989). Secondary oxidation products in the form of malonaldehyde were analyzed in the methanol-water layer of the extracts using the method of Schmedes and Hølmer (1989). Dienes and trienes were analyzed in the chloroform extracts following their ten-fold dilution. The absorbance was measured in the full range of UV. Intensive band was observed for dienes for the wavelength of $242 \mathrm{~nm}$, while for 
trienes-for the wavelength of $278 \mathrm{~nm}$. The results were expressed in a form of absorption coefficient (Paquot 1979).

Analysis of the lipid content in the muscle tissue of the herring was preformed using the weight method after distilling off the chloroform and the extracts and after drying the remainder at $80^{\circ} \mathrm{C}$ for 1 hour.

All chemical analyses were repeated three times.

Antioxidative activity of the additives used was calculated using the mean values of the respective chemical indicators in explored samples in relation to those in control sample, expressed in percent (Al-Saikchan et al. 1995).

\section{RESULTS AND DISCUSSION}

The muscle tissue sampled for analysis contained $6.8 \%$ of lipids. During the frozen storage of all experimental treatments of the minced meat, variations in the extractibility of lipids were observed, especially in the muscle tissue containing BHA (Tab. 1). A similar effect of BHA on the extractibility of lipids was observed in the other studies and it was associated with decreased solubility of proteins in $5 \%$ solution of $\mathrm{NaCl}$ (Stodolnik and Samson 1996). It may suggest an impact of this antioxidant on formation of protein-lipid structures.

Table 1

Effects of ground seeds of the mustard and their extracts on changes in the content of lipids (\%) in the muscle tissue of herring during frozen storage

\begin{tabular}{|ll|c|c|c|c|c|c|c|}
\hline \multicolumn{2}{|c|}{ Sample } & \multicolumn{8}{|c|}{ Storage time (weeks) } \\
\cline { 3 - 8 } & 0 & 2 & 4 & 6 & 9 & 11 & 13 \\
\hline Control & & 6.8 & 6.0 & 6.5 & 5.8 & 9.1 & 6.5 & 6.9 \\
Additive: & G-0.25\% & 6.8 & 6.6 & 6.3 & 7.2 & 6.8 & 6.6 & 5.0 \\
& G-0.50\% & 6.8 & 6.9 & 5.3 & 6.7 & 6.8 & 6.3 & 6.2 \\
G-0.75\% & 6.8 & 6.6 & 5.7 & 6.7 & 5.3 & 6.3 & 6.1 \\
GE-0.50\% & 6.8 & 6.5 & 5.7 & 4.1 & 5.7 & 6.6 & 5.7 \\
GE-0.75\% & 6.8 & 5.5 & 5.8 & 6.8 & 5.4 & 6.4 & 6.2 \\
BHA-0.01\% & 6.8 & 6.6 & 4.3 & 6.4 & 9.8 & 6.4 & 6.7 \\
\hline
\end{tabular}

$\mathrm{G}$-ground seeds of the mustard

GE- extract of the mustard seeds

During the frozen storage of the muscle tissue of herring the lipids were oxidized to hydroperoxides. The latter process was the most intensive up to 6th week of the storage of all experimental samples (Fig. 1). The content of hydroperoxides in the samples enriched with the white mustard or the extracts of its seeds, in individual storage periods was higher in most cases, than the content of these products in control sample. All samples of the 
minced meat, supplemented with the white mustard seeds, throughout the entire experimental period exhibited prooxidative actions. It was in a reverse proportion to the content of the white mustard. Aqueous extracts of white mustard had smaller effect on catalyzing oxidation of lipids of the muscle tissue to hydroperoxides. Extracts of 0.5 and $0.75 \%$ did not differ in their effect (Tab. 2). Effective inhibition of lipid oxidation of herring to primary products of oxidation was achieved in the samples supplemented with buthylated hydroxyanisole--a similar result as obtained in the earlier study on the same raw material (Stodolnik and Samson 1996).
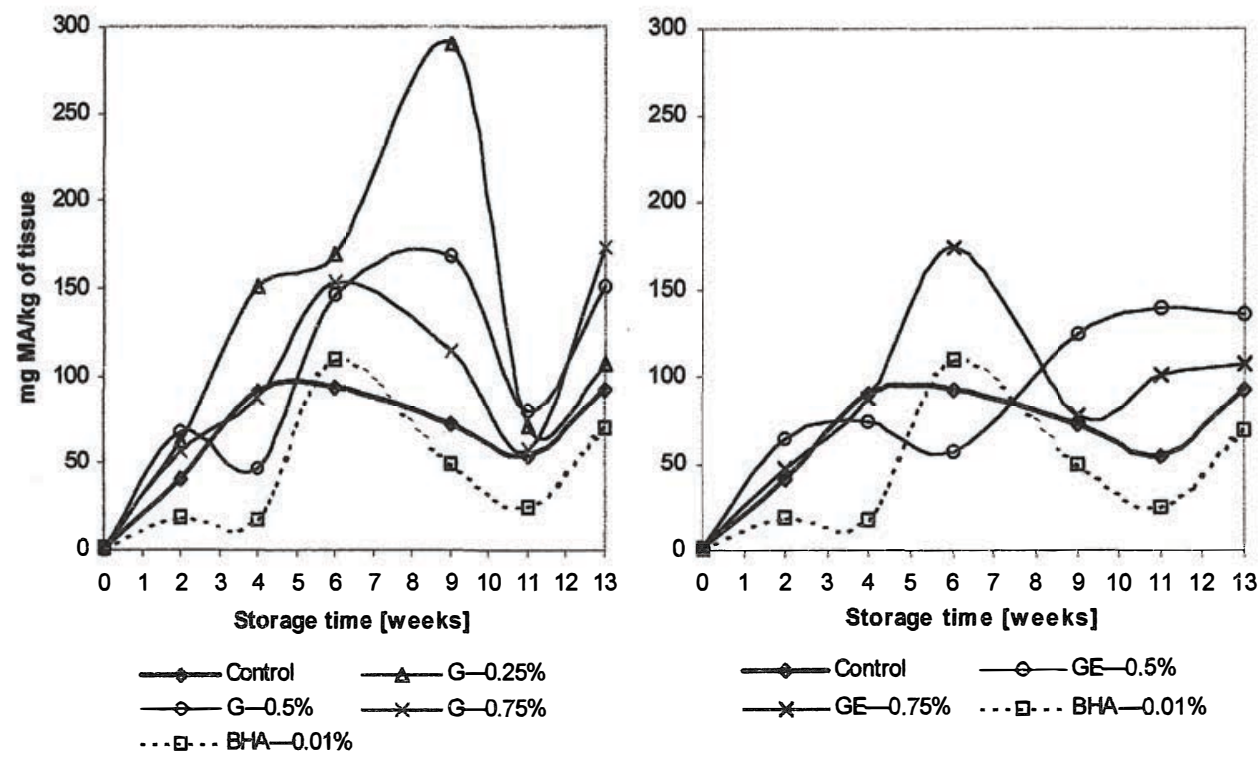

Fig. 1. Effects of ground seeds of the mustard and their extracts on changes in the content of hydroperoxides in the muscle tissue of herring during frozen storage (chloroform layer of the extracts)

Table 2

Antioxidative activity (\%) of the additives used to the muscle tissue of herring during frozen storage

\begin{tabular}{|l|c|c|c|r|r|}
\hline \multicolumn{1}{|c|}{ Additive } & Hydroperoxides & Malonaldehyde & Dienes* & Trienes & Total \\
\hline G $-0.25 \%$ & -91.74 & 17.54 & -3.32 & 0.40 & -17.64 \\
G $-0.50 \%$ & -48.81 & 31.29 & -5.54 & 2.19 & -2.45 \\
G-0.75\% & -44.72 & 42.36 & -7.89 & 4.97 & 2.62 \\
GE $-0.50 \%$ & -33.92 & 40.67 & -11.21 & -10.14 & 1.95 \\
GE $-0.75 \%$ & -33.72 & 49.18 & -5.76 & 1.59 & 5.70 \\
BHA - $0.01 \%$ & 35.17 & 78.46 & 6.28 & 22.66 & 32.50 \\
\hline
\end{tabular}

*minus values recognised a positive effect of the additives

$\mathrm{G}$-ground seeds of the mustard

GE-extract of the mustard seeds 
The seeds of the white mustard turned out to be good inhibitors of oxidation of the muscle tissue lipids to secondary products of oxidation. They demonstrated better lipidprotective effects while used in higher quantities (Fig. 2; Tab. 2). Addition of the white mustard extracts to the muscle tissue inhibited lipid oxidation to aldehydes more effectively than addition of white mustard seeds. A better antioxidative effect was observed for the extract concentration of $0.75 \%$ than for $0.50 \%$, but it was not a proportional relationship (Fig. 2; Tab. 2). Among the plant-origin additives used in the present study the best effects in inhibition of the lipids of the herring muscle tissue to secondary products were achieved through the extract of the white mustard seeds in the amount of $0.75 \%$. Its antioxidative activity was $49.2 \%$. It was followed by the white mustard seed in concentration of $0.5 \%$ (antioxidative activity $42.4 \%$ ) and mustard seeds extract in concentration of $0.5 \%$, resulting in antioxidative activity of $40.7 \%$. Both of the above-mentioned additives, however, had lower antioxidative potential than BHA. Antioxidative activity of the highest concentrations of these additives constituted respectively about 54 and $63 \%$ of the BHA activity. Antioxidative activity of BHA calculated based on the secondary products of oxidation was $78.5 \%$ and it was over 2.5-times higher, than determined for this antioxidant in the earlier studies (Stodolnik and Samson 1996; Stodolnik and Andrzejewski 1998).
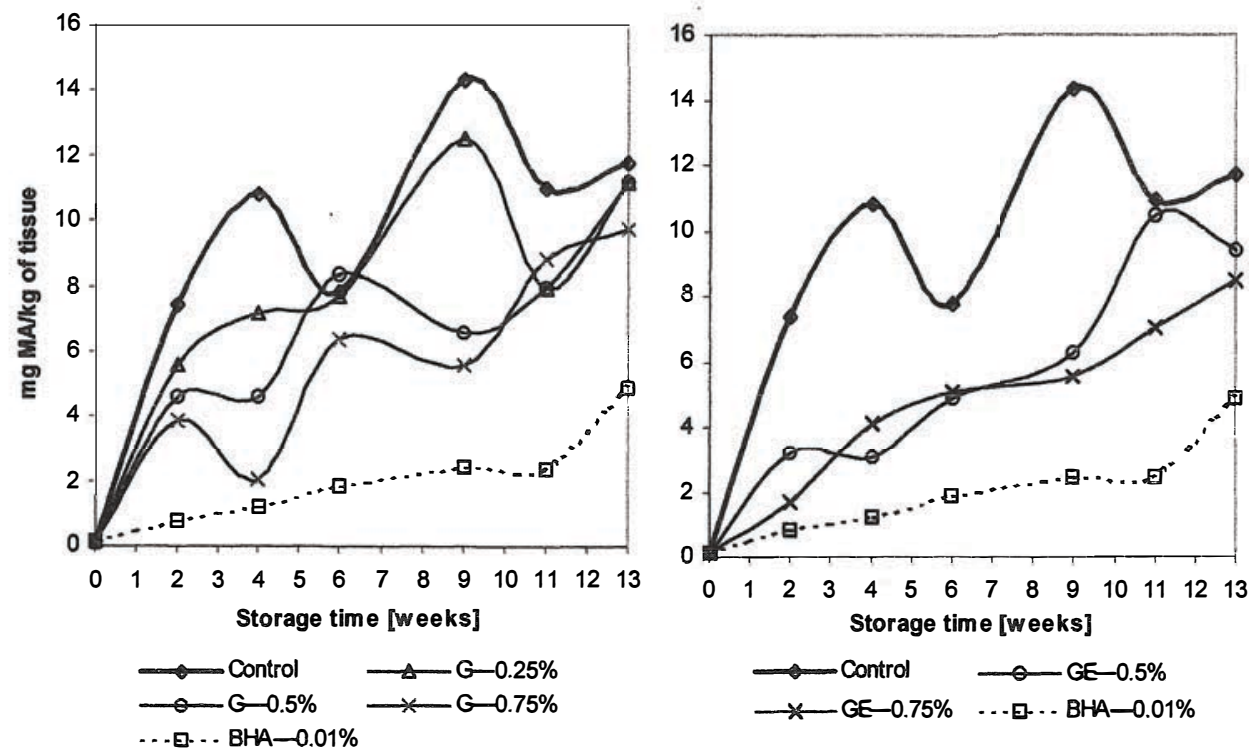

Fig. 2. Effects of ground seeds of the mustard and their extracts on changes in the content of secondary oxidation products in the muscle tissue of herring during frozen storage (methanol-water layer of the extracts) 
The present study revealed that all of the forms of the white mustard added to the minced muscle tissue of herring had elevated the activity of conjugated fatty acids (Tabs. 3, 4). BHA relatively weakly inhibited the buildup of dienes, being more effective in the inhibition of trienes (Tab. 4).

Table 3

Effects of ground seeds of the mustard and their extracts on changes of the dienes (as the absorption coefficient) in the lipids of the muscle tissue of herring during frozen storage

\begin{tabular}{|ll|c|c|c|c|c|c|c|}
\hline \multicolumn{2}{|c|}{ Sample } & \multicolumn{8}{|c|}{ Storage time (weeks) } \\
\cline { 3 - 8 } & 0 & 2 & 4 & 6 & 9 & 11 & 13 \\
\hline Control & & 7.6 & 3.4 & 6.9 & 6.9 & 5.1 & 7.4 & 6.5 \\
Additive: & G-0.25\% & 7.6 & 2.9 & 6.9 & 5.6 & 6.6 & 7.2 & 8.1 \\
& G-0.50\% & 7.6 & 2.7 & 8.1 & 5.9 & 6.5 & 7.9 & 6.9 \\
& G-0.75\% & 7.6 & 3.1 & 7.4 & 6.1 & 8.1 & 7.3 & 6.9 \\
GE-0.50\% & 7.6 & 3.6 & 7.4 & 7.5 & 7.6 & 6.6 & 7.5 \\
GE-0.75\% & 7.6 & 2.7 & 7.7 & 5.9 & 7.7 & 7.3 & 6.9 \\
BHA-0.01\% & 7.6 & 2.9 & 7.4 & 6.6 & 4.2 & 6.0 & 6.7 \\
\hline
\end{tabular}

$\mathrm{G}$ - ground seeds of the mustard

GE - extract of the mustard seeds

Table 4

Effects of ground of the mustard and their extract on changes of the trienes (as the absorption coefficient) in the lipids of the muscle tissue of herring during frozen storage

\begin{tabular}{|ll|c|c|c|c|c|c|c|}
\hline \multicolumn{2}{|c|}{ Sample } & \multicolumn{9}{|c|}{ Storage time (weeks) } \\
\cline { 3 - 8 } & 0 & 2 & 4 & 6 & 9 & 11 & 13 \\
\hline Control & & 0.63 & 0.66 & 0.53 & 1.21 & 0.96 & 1.02 & 0.65 \\
Additive: & G-0.25\% & 0.63 & 0.53 & 0.65 & 0.73 & 1.04 & 1.00 & 1.06 \\
& G-0.50\% & 0.63 & 0.39 & 0.76 & 0.84 & 1.10 & 1.12 & 0.71 \\
& G-0.75\% & 0.63 & 0.57 & 0.31 & 0.91 & 1.44 & 0.84 & 0.71 \\
& GE-0.50\% & 0.63 & 0.90 & 0.46 & 1.51 & 1.06 & 0.78 & 0.83 \\
& GE-0.75\% & 0.63 & 0.58 & 0.30 & 1.04 & 1.22 & 1.10 & 0.71 \\
BHA-0.01\% & 0.63 & 0.53 & 0.48 & 1.03 & 0.45 & 0.69 & 0.71 \\
\hline
\end{tabular}

$\mathrm{G}$ - ground seeds of the mustard

GE - extract of the mustard seeds

Observed in the present study, good properties of the white mustard seeds in inhibiting oxidation of the herring muscle tissue to secondary products is an effect of action of its chemical components. Typical components occurring in the white mustard are mucous substances present in its husk (15-18\%) and particularly in its inside (22-35\%) and proteins (28-37\%) (Niewiadomski 1984; Ożarowski and Jaroniewski 1989). The mucous substances 
present in the seeds of the white mustard are composed of polysaccharides, which jointly with proteins, can effectively inhibit oxidation of lipids of the muscle tissue of herring. The typical compounds in the mucous are usually glycoproteins. Their high potential in inhibiting lipid oxidation has been proven (Al-Saikhan et al. 1995). It can be concluded, based on the present study, that antioxidative properties have the mucous substances from white mustard, in particular, because the aqueous extracts of the white mustard had higher antioxidative properties in relation to the lipids of the muscle tissue of herring, than whole grind seeds.

It can be expected, that certain antioxidative properties of the white mustard can be attributed to sinalbin (isocitrate, derivative of tyrosine) (Kączkowski 1985). As it is commonly known, the majority of amino acids have lipid-protective properties (Riison et al. 1980; Ahmad et al. 1983).

According to Dobrowolski (1968) sinalbin hydrolyzes into glucose, mustard oil, and sulfuric acid. In addition, saccharides and amino acids present in the white mustard, under certain conditions can transform into Maillard reaction products, known to show antioxidative properties in many products (Chiu et al. 1991; Elizalde et al. 1992; Gow-Chin-Yen and Li-Chin-Tsai 1993).

According to Kączkowski (1985) white mustard oils are sulfur compounds containing this element in two oxidative forms $\mathrm{S}^{2-}$ and $\mathrm{S}^{6+}$. The radicals of the white mustard oils are derived from amino acids. It can be demonstrated by the structural similarity as well as by isotope studies on their biosynthesis (Kączkowski 1985). Sulfur amino acids in some lipid substrates may show prooxidative properties (Marcuse 1962). It is possible that the white mustard oils in the conditions of unstable lipids of the muscle tissue of herring contributed to acceleration of their oxidation to hydroperoxides during frozen storage of the fish raw material.

Higher content of dienes detected in the course of the present study in the lipids of the muscle tissue of herring treated with the white mustard seeds exceeding the content of this compound in the sample without the additive can be considered a positive result in the light of the other studies (Ha et al. 1990; Chin et al. 1992). The above-mentioned papers indicated anticarcinogenic properties of conjugated fatty acids. It is possible that conjugated fatty acids are the natural components of the seeds of the white mustard. As it is evident from the literature, seeds of certain plants can be a source of such acids (Hopkins 1972). Conjugated fatty acids occur in the lipids of the muscle tissue of Baltic herring as their native components. In the hitherto conducted studies on their content in the muscle tissue of this fish species, sampled in various months of a year, the following content of dienes and trienes, expressed in a form of absorption coefficients have been reported: 3.5-6.0 and 
0.45-0.80 respectively (Stodolnik 1994, 1995, 1996; Stodolnik and Samson 1996). In the present study the values representing dienes and trienes were 7.50 and 0.63 respectively.

The white mustard in the conditions of the muscle tissue of herring turned out to be a good inhibitor of changes of hydroperoxides to aldehydes, which indicates its effectiveness in "sweeping" active radicals occurring on the beginning of the oxidation process during frozen storage.

\section{CONCLUSIONS}

1. The muscle tissue of herring supplemented with the white mustard seeds in particular aqueous extract of white mustard seeds showed distinctly smaller oxidation to aldehydes than the tissue without these additives during a three-month-long storage at $-25^{\circ}$. Antioxidative activity of these additives constituted about 54 and $63 \%$ (respectively) of BHA activity.

2. Oxidation of lipids of the muscle tissue of herring to hydroperoxides and dienes was not inhibited by the addition of white mustard in any form and concentration during frozen storage.

3. Weak inhibition properties related to the buildup of triene compounds of fatty acids of the muscle tissue of herring were shown by the addition of white mustard seeds in each form used and by $0.75 \%$ extract.

4. Muscle tissue of herring containing the addition of BHA was characterized by the lowest content of all analyzed products of oxidation during frozen storage.

5. The overall antioxidative activity of the additives used, considering all analyzed products of oxidation of the lipids of the muscle tissue of herring during three-month-long frozen storage was as follows: $\mathrm{BHA}>\mathrm{GE} 0.75 \%>\mathrm{G} 0.75 \%>\mathrm{GE} 0.50 \%$ (Where GE-aqueous extract of the white mustard; G-ground seeds of the white mustard).

\section{REFERENCES}

Ahmad M.M., S. Al-Hahim, A.A.Y. Shehata, 1983: The antioxidant activity of amino acids in two vegetable oils. J. Am. Oil Chem. Soc., 60: 837-840.

Al-Saikhan M.S., L.R. Howard, J.C. Miller, 1995: Antioxidant activity and total phenolics in different genotypes of potato (Solanum tuberosum, L.). J. Food Sci., 60: 341-343, 347.

Ames B.N., 1983: Dietary carcinogenesis and anticarcinogenes. Oxygen radicals and degenerative diseases. Science, 221: 1256-1264.

Block G., 1992: The data support of a role for antioxidants reducing cancer risk. Nutrit. Rev., 50: 207-213. 
Chin S. F., W. Liu, J. M. Storkson, Y. L. Ha, M. W. Pariza, 1992: Dietary sources of conjugated dienic isomers of linoleic acid, a newly recognized closs of anticarcinogens. J. Food Comp. Anal., 5: 185-197.

Chiu W.K., M. Tanaka, Y. Nagashima, T. Taguchi, 1991: Studies on antioxidative Maillard reaction products. II. Prevention of sardine lipid oxidation by antioxidative Maillard reaction products prepared from fructose - tryptofan. Bull. Jap. Soc. Sci. Fish., 57: 1773-1781.

Elizalde B.E., F. Bressa, M.D. Rosa, 1992: Antioxidative action of Maillard reaction volatiles: influence of Maillard solution browning level. J. Am. Oil Chem. Soc., 69, 4: 331-334.

Dobrowolski J., 1968: Biochemia [Biochemistry]. WSR Szczecin, 172. (In Polish).

Gow-Chin-Yen, Li-Chin-Tsai, 1993: Antimutagenicity of a partially fractionated Maillard reaction products. Food Chem., 47, 1: 11-15.

Grau J., R. Jung, B. Münker, 1996: Leksykon przyrodniczy. Zioła i owoce leśne [Encyclopedic dictionary of natural science. Herbs and fruits of forest]. Geo Center International, Warszawa, 84, 263. (In Polish).

Ha Y.S., J. Storkson, M. W. Pariza, 1990: Inhibition of benzo(a)pyrene-induced mouse forestomach neoplasia by conjugated dienoic derivatives of linoleic acid. Cancer. Res., 50: 1097-1101.

Hopkins C.Y., 1972: Fatty acids with conjugated unsaturation. In: Topics in lipid chemistry [Gunstone F.D. (ed.)] v. 3. Elek Science, London: 37-87.

Kączkowski J., 1985: Biochemia roślin [Plant Biochemistry]. PWN, Warszawa: 2, 192-198, 203-207. (In Polish).

Linko R.R., 1967: Fatty acids and other components of Baltic herring flesh lipids. Anu. Univ. Turku Serv. A., 101: 7-121.

Marcuse E., 1962: The effects of some amino acids on the oxidation of linoleic acid and its methyl ester. J. Am. Oil Chem. Soc., 39, 2: 97-103.

Murphy M.G., 1990: Dietary fatty acids and membrane protein function. J. Nutr. Biochem., 1: 68-77.

Niewiadomski H., 1984: Surowce thuszczowe [Lipid raw materials]. WNT, Warszawa: 100-102. (In Polish).

Nowiński M., 1980: Dzieje upraw i roślin leczniczych [History of crops and medicine plants]. PWRiL, Warszawa: 82-83. (In Polish).

Ożarowski A., W. Jaroniewski, 1989: Rośliny lecznicze i ich praktyczne zastosowanie [Medicine plants and their practical using]. Inst. Wyd. Związków Zawodowych, Warszawa: 165-166. (In Polish).

Paquot C., 1979: Standard methods for the analysis of oils, fats and derivatives. Pergamon Press: 71-74.

Ramanathan L., N.P. Das, 1993: Natural products inhibit oxidative rancidity in salted cooked ground fish. J. Food Sci., 58: 318-320, 360.

Riison T., R.J. Sims, J.A. Fioriti, 1980: Effect of amino acids on the autoxidation of sunflower oil in emulsions. J. Am. Oil Chem. Soc., 57: 354-359.

Schmedes A., G. Hølmer, 1989: A new thiobarbituric acid (TBA) method for determining free malondialdehyde (MDA) and hydroperoxides selectively as a measure of lipid peroxidation. J. Am. Oil Chem. Soc., 66, 6: 813-817.

Stodolnik L., 1994: Zastosowanie naturalnych antyoksydantów do rozdrobnionej tkanki mięśniowej śledzi bałtyckich przechowywanej $\mathrm{w}$ warunkach zamrażalniczych [Usage of natural antioxidants to minced muscle tissue of the Baltic herring stored under frozen conditions]. Chłodnictwo, 10: 21-25.

Stodolnik L., 1995: Activity of selected plant raw materials in inhibition lipids changes Baltic herring minced meat tissue during frozen storage. Acta Ichth. Piscat., 25, 1: 79-87. 
Stodolnik L., 1996: Inhibition of lipids oxidation in the minced muscle tissue of herring through usage of selected fruits in the conditions of freezing storage. Acta Ichth. Piscat., 26, 1: 61-70.

Stodolmik L., R. Andrzejewski, 1997: Impact of selected mushrooms on inhibitions of lipid oxidation of the muscle tissue of herring during frozen storage. Acta Ichth. Piscat., 27, 2: 165-172.

Stodolnik L., Samson E., 1996: Inhibition of lipid oxidation in the minced muscle tissue of the Baltic herring through usage of hawthorn and elader flowers in the conditions of frozen storage. Acta Ichth. Piscat. 26, 2: 125-135.

Taniguchi M., Y. Yano, E. Tada, K. Ikenishi, S. Oi, H. Haraguchi, K. Hashimoto, I. Kubo, 1988: Mode of action of polygodial, an antifungal sesquiterpene dialdehyde. Agric. Biol. Chem., 52: 1409-1414.

\section{Ludmiła STODOLNIK, Grzegorz SZCZEPANIK}

\section{HAMOWANIE UTLENIANIA LIPIDÓW MROŻONEJ TKANKI MIĘŚNIOWEJ ŚLEDZI PRZEZ ZASTOSOWANIE GORCZYCY}

\section{STRESZCZENIE}

Analizowano, w czasie trzymiesięcznego przechowywania w temperaturze $-25^{\circ} \mathrm{C}$, proces utleniania zmielonej tkanki mięśniowej śledzi bałtyckich, zawierającej dodatek nasion gorczycy białej w ilości 0,$25 ; 0,50$; i 0,75\% lub ekstraktu wodnego z tych nasion w ilości 0,50 i $0,75 \%$ odpowiadający dodatkowi gorczycy do farszu mięsnego ze śledzi odpowiednio 0,50 i $0,75 \%$. Oznaczano zawartość hydronadtlenków, wtórnych produktów utleniania, dienów i trienów.

Uzyskane wyniki wykazały, że utlenianie lipidów tkanki miesśniowej śledzi do aldehydów było spowalniane przez nasiona gorczycy, a szczególnie przez ekstrakt wodny z jej nasion. Aktywność przeciwutleniająca najwyższych stężeń tych dodatków stanowiła odpowiednio ok. 54 i $63 \%$ aktywności BHA. Utlenianie lipidów tkanki mięśniowej śledzi do hydronadtlenków oraz nagromadzanie się skoniugowanych kwasów tłuszczowych (dieny) w czasie zamrażalniczego przechowywania nie było inhibitowane przez dodatek gorczycy, niezależnie od jej postaci i stężenia. Najmniejszą zawartością wszystkich analizowanych produktów utleniania w czasie zamrażalniczego przechowywania charakteryzowała się tkanka mięśniowa śledzi z dodatkiem BHA.

Ogólna aktywność antyoksydacyjna zastosowanych dodatków, uwzględniająca wszystkie analizowane produkty utleniania lipidów tkanki mięśniowej śledzi podczas trzymiesięcznego przechowywania zamrażalniczego, układała się następująco: $\mathrm{BHA}>\mathrm{GE} 0,75 \%>\mathrm{G} 0,75 \%>\mathrm{GE} 0,50 \%$.

Received: 2 November 1998

Authors' address:

Ludmiła Stodolnik PhD DSc Prof Tit

Department of Refrigeration

Agricultural University of Szczecin

Kazimierza Królewicza 4, 71-550 Szczecin, Poland 